\title{
Transparent façades - selection of construction materials with the use of modified multi-criteria spider's network analysis method
}

\author{
Oliwier Zapała ${ }^{1}$, and Damian Wieczorek ${ }^{1, *}$ \\ ${ }^{1}$ Cracow University of Technology, Faculty of Civil Engineering, Institute of Construction \\ Management, 31-155 Kraków, Warszawska street 24, Poland
}

\begin{abstract}
The article deals with transparent façades of public buildings which are the main and most impressive elevations of the building. It also focuses on some issues related to high requirements placed on façade systems in terms of insulation from environmental conditions and comfort of the future users of the building. Due to the fact that there are many materials that can be used for the main structural elements (columns, spandrel beams and ribs) of load-bearing façade structures, the authors of the article attempted to do a multi-criteria comparative analysis of three different materials (safety glass, glulam and rolled steel) of a 6-meter-long reference column. The set of criteria, consisting of twelve elements, was adopted for comparative analysis. A combination of two methods was selected for performing the multi-criteria analysis: a geometric method of spider's network and a mathematical method of the adjusted index of summation.
\end{abstract}

\section{Introduction}

At present transparent façades dynamically begin to mark their presence in construction. With increasing frequency, architects try to use glass as the basic façade material in their projects, and its application is primarily determined by aesthetic qualities. Due to the developing trend, new technologies and new possibilities for using façades of this type in construction are emerging [1].

According to the definition presented in [2], the façade is the main and the most impressive façade, with a particularly large decoration, which fulfills the representative functions of the entire building, thus standing out from other façades. Transparent façades can perform representative functions; however, due to the specificity of their construction (as in, e.g. frameless glass façades), they often require a merge of glass panes with the loadbearing façade structure, which can be constructed of many materials used for the main structural elements (columns, spandrel beams and ribs).

The main aim of the study is a multi-criteria comparative analysis of three different materials (safety glass, glued laminated timber - glulam and rolled steel) of a 6-meter-long reference column. The material selection process for the load-bearing structure is treated

*Corresponding author: dwieczorek@L3.pk.edu.p1 
with regard to the decision making problem that one may face in the process of choosing the best solution based on the criteria that interest the decision maker [3-5].

\section{Types and basic properties of building glass}

Glass is a material that in construction is used not only for the production of windows, thermally insulating elements, hollow blocks or glass roof tiles, but also for panes, glazing units and main structural elements on the elevations of cubature buildings.

Glass is an amorphous inorganic material which is created in the process of rapid cooling of the liquid to a solid state without the crystallization step [6]. Glass has numerous physical and mechanical features [6,7]. Glass is a substance without an ordered internal structure, because of which it lacks the constant melting temperature and is a poor conductor for electricity. Glass is an isotropic material, with high chemical resistance, with good acoustic insulation but poor thermal insulation (its thermal conductivity $[\lambda]$ is about $0.80-1.00 \mathrm{~W} / \mathrm{mK}$ ). The density of construction glass is $2400-2600 \mathrm{~kg} / \mathrm{m}^{3}$ and is comparable to the density of reinforced concrete. The glass hardness is measured on the Mohs scale and ranges from 5 to 7 . The bending strength of glass varies from 30 to $50 \mathrm{MPa}$ and is greater than $32 \mathrm{MPa}$ for top-class glulam (GL32h, GL32c). Its compressive strength is in the range from 800 to $1000 \mathrm{MPa}$, that is, up to 5 times higher than for very high strength concrete (about 180-200 MPa) and comparable to the ultra-high strength concrete, but very rarely used in construction. Young's modulus for glass is $70 \mathrm{GPa}$.

The most negative feature of glass is its brittleness. Glass, when reaching maximum strength, undergoes sudden cracks without giving any indication of loss of load capacity, as opposed to steel (which undergoes deformation), wood (which creaks before the loss of load capacity) or concrete (which is scratched in an emergency condition) [1].

In construction the following types of glass are used [1, 6-9]:

- Sodium-calcium-silicate glass and boron-silicate glass, which are characterized by high resistance to aggressive chemical compounds,

- Float glass, which is the basic type of glass obtained in the melting process of raw materials (quartz sand, additives in the form of sodium and calcium carbonate, fluxes, i.e. boron and lead oxides, and cullet),

- ESG, i.e. toughened glass, which arises in the process of heating Float glass at a temperature of approx. $700^{\circ} \mathrm{C}$ and (then) rapid cooling, which shapes such a system of internal stresses, which increases the strength parameters of glass several times and heightens the range of glass resistance to rapid changes in temperature; ESG glass breaks (after shattering) into small, blunt pieces, which is why it is classified as safety glass; ESG glass should not be machined,

- TVG, i.e. semi-hardened glass, one that is heat-strengthened in the heating process at a temperature of approx. $625^{\circ} \mathrm{C}$, which is (then) cooled more slowly than in the case of the ESG glass, using water, which results in approx. twice the bending strength compared to Float glass; TVG glass is also a safety glass, breaking into slightly larger, but also blunt pieces as in the case of ESG glass; TVG glass should not be machined,

- VSG, i.e. glued (or laminated) glass, which is created by connecting several sheets of Float, ESG or TVG glass with polyvinyl butyral PVB film or acrylic resins cured chemically with UV radiation; glass joining technology via PVB requires the use of autoclaving which consists in heating the package to $115^{\circ} \mathrm{C}$, at a pressure of about 10 bars; VSG glass is also a type of safety glass, because in the case of a crack, the laminated glass does not break down into small fragments but sticks to the PVB film.

\section{Characteristics of transparent façades}




\subsection{Basic requirements for transparent façades}

Transparent façades, as well as other outer partitions, need to meet requirements concerning insulation from environmental conditions and providing comfort to users of the building. These requirements can be reduced to the following issues related to: thermal protection, anti-noise protection, fire resistance and protection against biological and/or chemical corrosion [8]. Due to the dissimilarity of glass products to other, most common building materials (e.g. glulam, concrete, ceramic, or steel), the authors will describe more broadly only the requirements related to thermal protection and fire resistance. As it was already indicated in chapter 2 of the paper, building glass is a material that is perfectly resistant to chemical agents and makes a good acoustic insulation.

The requirements concerning heat protection are directly related to the need to save energy. In the Regulation of the Minister of Infrastructure of April 12, 2002 regarding technical conditions which should be met by buildings and their location (Journal of Laws of 2015, item 1422), which pursuant to the amending Regulation of the Minister of Infrastructure and Construction of November 14, 2017 (item 2285), correction were made in the entries related to, e.g. the limit values of heat transfer coefficient $\left(U_{\max }\right)$ for windows, balcony doors, external doors and transparent non-opening surfaces (including transparent façades), for all types of buildings, in such a way that the values $\left(U_{\max }\right)$ can not be greater than $1.1 \mathrm{~W} / \mathrm{m}^{2} \mathrm{~K}$ if the temperature inside the heated space $\left(t_{i}\right)$ is equal to or greater than $16^{\circ} \mathrm{C}$. It is worth adding that before the legal changes mentioned above, the limit value $\left(U_{\max }\right)$ was $1.8 \mathrm{~W} / \mathrm{m}^{2} \mathrm{~K}$ and was by as much as $63.6 \%$ higher than the current one.

In the case of requirements related to fire resistance, it should be noted that although glass products become increasingly more common in construction, are characterized by differences in issues related to fire protection. As the publication by [8] states, single-layer silicate glass cracks and falls out of the frame at a temperature of about $200^{\circ} \mathrm{C}$. A much better fire resistance is the feature of glued glass (VSG) which, combined with an additional reinforcing mesh between the layers, gives the fire resistance class (fire integrity expressed in minutes) E30. Single-layer glass with embedded reinforcing mesh can achieve fire integrity at the E60 level (unless the glass panes are too large), while the modified boron-silicate glass, for reasons of much longer resistance to high temperatures, can achieve the fire resistance class E90, and even E120, if the panes are not too large.

\subsection{Types of transparent façades}

There are two basic types of glass façades $[8,9]$ : single, which are usually composed of two or three panes of glass between which there is a partition in the form of space separated from the surroundings and double, which consist of two glass surfaces forming a gap through which the air flows (the so-called ventilated façades).

In the case of single façades, it is not possible to determine the recommended thickness of the façade clearly, because individual systems differ considerably in terms of thermal insulation properties. The typical thickness range of such façades varies from a few to even $150 \mathrm{~mm}$. The single façades are usually made of ordinary glass, glued VSG, hardened ESG or semi-hardened TVG. All glass types are characterized by low thermal insulation due to the high value of the thermal conductivity coefficient $(\lambda)[9]$.

Double façades have been used for a short time and because of their better thermal insulation parameters are called climatic façades [10]. They consist of two glass surfaces that create a gap that allows the air to flow. The distance between these surfaces typically ranges from 100 to even $2000 \mathrm{~mm}$. Double façades are characterized by acoustic protection, thermal insulation and high efficiency of heat recovery [10]. 
Due to the type of fixing, glass façades are divided into [7, 9]: frameless ones, the essence of which is point fixing of glass panels to an independent load-bearing structure and with framing, in which glass panes are typically fastened to steel or aluminium profiles.

Frameless façades are characterized by greater freedom in forming glazing in buildings. The most important issue in the design and implementation of these structures is the appropriate selection of connections [7]. Connections between glazing units should also be selected on the grounds of aesthetics and economics considerations of the solution applied.

In the case of the façade with framing, the most important issue is the appropriate selection of static schemes and the system used in relation to the entire facility. Depending on the chosen façade system, the designer should provide an additional supporting structure, which will carry permanent loads from the tare weight of the façade and the variables from the wind [7]. The adoption of the right concept and selection of appropriate construction schemes can significantly reduce the investment costs of a construction project, which is particularly noticeable in the case of high façades [1].

\subsection{Examples of implementation of transparent façades}

Transparent façades are increasingly used in building construction. One can identify many implementations of office buildings or public utilities (sports halls, indoor riding schools, swimming pools, or cultural facilities) whose façades were designed and made as glass façades with frame or as frameless structures [1]. As shown by numerous frameless façades, load-bearing structures can now be made not only from the most popular construction materials (glulam, steel or aluminium), but also from safety glass [11].

Figures 1 and 2 illustrate example implementations of transparent façades in public buildings related to culture. Figure 1 (Lesser Poland Garden of Art in Krakow) depicts a frame façade attached to steel elements. Figure 2 (The Chopin Museum in Żelazowa Wola) shows a frameless façade, in which an independent supporting structure for glazing elements creates a column and spandrel beams system made of safety glass VSG.

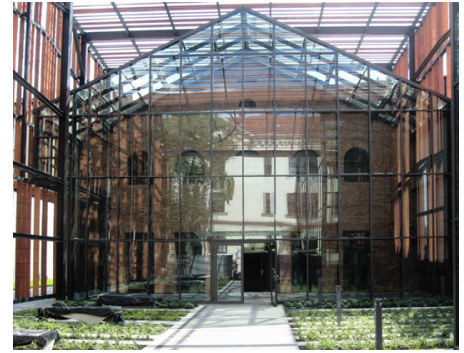

Fig. 1. Main façade of the Lesser Poland Garden of Art in Krakow; source: [12].

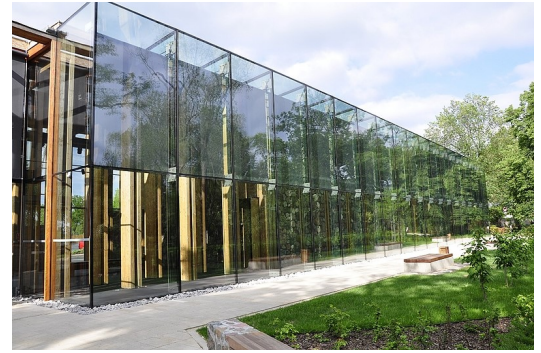

Fig. 2. Main façade of the The Chopin Museum in Żelazowa Wola; source: [13].

\section{Multi-criteria comparative analysis of construction materials for load-bearing façade structures}

As already mentioned in chapter 1 , the specificity of frameless transparent façades requires the connection of glass panes with the load-bearing façade structure, which can be made of many materials used for the main structural elements (columns, spandrel beams and ribs). Due to this fact, the authors of the study attempted to perform a multi-criteria comparative analysis of three different materials on a 6-meter-long reference column: 1 - safety glass with cross-sectional dimensions $80 \times 400 \mathrm{~mm}, 2$ - glulam with cross-sectional dimensions $160 \times 500 \mathrm{~mm}$ and 3 - steel rolled section IPE360. 
In this study, the material selection process has been treated with regard to the decision making problem that one may face in the process of choosing the best solution based on the criteria that interest the decision maker [3-5]. In the Polish literature, there are many publications that discuss a multi-criteria choice of alternative solutions for different decision problems. In the case of construction, the following solution variants are multicriteria evaluated and, typically, hierarchized (from the most to the least favourable): constructional material $[14,15]$, technological $[16,17]$ and installation [18]. One can also indicate examples of multi-criteria comparative analyses focused only on environmental aspects for material solutions [19, 20] or supporting the bidding decision [21].

In the case of selecting the construction material for the load-bearing façade structure, a combination of two methods was chosen for performing the multi-criteria analysis: a geometric method of spider's network (assuming the local evaluation of variants in specific groups of criteria) and a mathematical method for formulating synthetic evaluations of the adjusted index of summation (using partial measures encoded for variants according to Neuman-Morgenstern) [3, 4].

The comparative analysis was performed in two stages. In the first stage, the material variants were assessed against each of the twelve criteria (locally, three criteria in each of the four groups). The spider's network method was used as there was no need to determine the weight of each criterion [4]. In the second stage, material variants were compared globally based on the adjusted index of summation (AIS, where the maximum can be 1.00).

\subsection{Typification and characteristics of the set of criteria}

The set of criteria $\left(C_{i}\right)$, consisting of twelve elements, was adopted for the comparative analysis, where: criterion $\left(C_{1}\right)$ is Cost of material, $\left(C_{2}\right)$ - Total initial cost, $\left(C_{3}\right)$ - Life cycle cost, $\left(C_{4}\right)$ - Degree of similarity to the main façade material, $\left(C_{5}\right)$ - Maintaining purity of element, $\left(C_{6}\right)$ - Resistance to mechanical damage, $\left(C_{7}\right)$ - Content of primary energy, $\left(C_{8}\right)$ Specific heat, $\left(C_{9}\right)$ - Thermal conductivity, $\left(C_{10}\right)$ - Weight of component, $\left(C_{11}\right)$ - Way of ensuring fire resistance and $\left(C_{12}\right)$ - Degree of chemical and biological corrosion resistance.

All criteria were categorized into one of four (three-element) groups: I - economic (criteria $\left.C_{1}-C_{3}\right)$, II - aesthetic $\left(C_{4}-C_{6}\right)$, III - energetic $\left(C_{7}-C_{9}\right)$ and IV - others $\left(C_{10}-C_{12}\right)$. For each criterion, the type (quantitative, qualitative) and character (stimulants which are positively correlated with the criterion, and negatively correlated - destimulants) were determined. Qualitative criteria have been described by applying a three-point scale. The value of the partial assessment of all qualitative criteria (for a given material variant) was determined by the experts. For each qualitative criterion, the scale has been selected: for $\left(C_{4}\right) 3$ means identical material (glass), 2 - natural material (glulam), 1 - different material (steel), for $\left(C_{5}\right) 3$ - easy, 2 - quite easy, 1 - quite difficult, for $\left(C_{6}\right) 3$ - good, 2 - average, 1 poor, for $\left(C_{11}\right) 3$ - by cross section (no coating required), 2 - by cross-section and coating, 1 - by coating or element housing, and for $\left(C_{12}\right) 3$ - good, 2 - average, 1 - poorly resistant.

In the case of quantitative criteria $\left(C_{3}\right),\left(C_{7}\right)$ and $\left(C_{8}\right)$, the Life cycle cost methodology according to [22] was used accordingly, including the costs incurred in the course of the operation for the continuous assurance of elements cleanliness and renewal of impregnating coatings (every 6 years but only for glulam) and content values of primary energy and specific heat for material variants that have been taken from the publication $[19,20]$.

\subsection{Locally evaluation of material variants in specific groups of criteria}

In the first stage, the material variants were assessed locally against each of the twelve criteria, which were listed in chapter 4.1. Due to the fact that all criteria were categorized into one of four three-element groups, the authors decided to use the spider's network 
method since it is quite simple and generates objective results for the three assessment criteria (as mentioned above). Partial measures of material variants were encoded to the form of the so-called measure of $i$-th variant according to $j$-th criterion $\left(z_{i j}\right)$, which is calculated for stimulants and destimulants according to the respective formulas [4]:

$$
z_{i f}=\frac{x_{i f}-x_{j \min }}{x_{j \max }-x_{i \min }} \quad z_{i f}=\frac{x_{j \max }-x_{i f}}{x_{j \max }-x_{i \text { min }}}
$$

where: $x_{i j}$ - partial measure of assessed variant according to the $j$-th criterion, $x_{j, \text { min }}$ minimum value of partial measure for $j$-th criterion and $x_{j, \max }$ - maximum value of partial measure for $j$-th criterion.

In the next step, the material variants were individually assessed in each of the four groups of criteria. For this purpose, a three-dimensional polar system was built for each variant (with $[x, y, z]$ axes) corresponding to three criteria in a given group (i.e. $\left[C_{1}\right],\left[C_{2}\right]$ and $\left.\left[C_{3}\right]\right)$ on the scale adopted with values from 0 to 1 on each axis. On the axes points corresponding to the encoded measures of variants are placed, which became the vertices of the polygon representing the analysed solution variant. Finally, the surfaces of the created polygons (SA) whose sizes could be compared with each other were calculated.

Table 1 presents the results of the analysis obtained in the first stage.

Table 1. The results of the analysis obtained in the first stage.

\begin{tabular}{|c|c|c|c|c|c|c|c|c|c|}
\hline \multirow{2}{*}{\multicolumn{2}{|c|}{ Criterion }} & \multirow{3}{*}{$\begin{array}{l}\text { Type, } \\
\text { char. }\end{array}$} & \multirow{3}{*}{$\begin{array}{c}\text { Unit } \\
\text { PLN/pcs }\end{array}$} & \multicolumn{3}{|c|}{$\begin{array}{c}\text { Partial and encoded }{ }^{*} \text { measures } \\
\text { of variants }\end{array}$} & \multicolumn{3}{|c|}{$\begin{array}{l}\text { Variants assessment } \\
\left(\text { SA }_{i}-\text { surface area) }\right.\end{array}$} \\
\hline & & & & \multirow{2}{*}{$\begin{array}{c}\begin{array}{c}\text { Safety } \\
\text { glass }\end{array} \\
3770.64 \\
(0.00)\end{array}$} & \multirow{2}{*}{$\begin{array}{c}\text { Glulam } \\
1137.60 \\
(1.00)\end{array}$} & \multirow{2}{*}{$\begin{array}{c}\begin{array}{c}\text { Rolled } \\
\text { Steel }\end{array} \\
2946.36 \\
(0.31) \\
\end{array}$} & $\begin{array}{l}\text { Safety } \\
\text { glass }\end{array}$ & Glulam & $\begin{array}{c}\text { Rolled } \\
\text { Steel }\end{array}$ \\
\hline \multirow{3}{*}{ 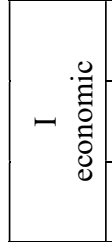 } & $C_{l}$ & & & & & & \multirow{3}{*}{0.00} & \multirow{3}{*}{0.73} & \multirow{3}{*}{0.35} \\
\hline & $C_{2}$ & $Q n, D$ & $\mathrm{PLN} / \mathrm{pcs}$ & $\begin{array}{c}5450.64 \\
(0.00)\end{array}$ & $\begin{array}{c}1972.38 \\
(1.00)\end{array}$ & $\begin{array}{c}3357.48 \\
(0.60) \\
\end{array}$ & & & \\
\hline & $C_{3}$ & $Q n, D$ & $\mathrm{PLN} / \mathrm{pcs}$ & $\begin{array}{c}45743.60 \\
(0.00)\end{array}$ & $\begin{array}{c}19405.56 \\
(0.75)\end{array}$ & $\begin{array}{c}10401.88 \\
(1.00)\end{array}$ & & & \\
\hline \multirow{3}{*}{ 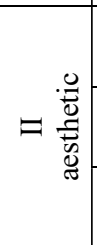 } & $C_{4}$ & $Q l, S$ & $\begin{array}{c}\text { Points } \\
1-3\end{array}$ & $\begin{array}{c}3 \\
(1.00) \\
\end{array}$ & $\begin{array}{c}2 \\
(0.50) \\
\end{array}$ & $\begin{array}{c}1 \\
(0.00) \\
\end{array}$ & \multirow{3}{*}{0.50} & \multirow{3}{*}{0.13} & \multirow{3}{*}{0.25} \\
\hline & $C_{5}$ & $Q l, S$ & $\begin{array}{c}\text { Points } \\
1-3\end{array}$ & $\begin{array}{c}1 \\
(0.00)\end{array}$ & $\begin{array}{c}2 \\
(0.50)\end{array}$ & $\begin{array}{c}3 \\
(1.00)\end{array}$ & & & \\
\hline & $C_{6}$ & $Q l, S$ & $\begin{array}{c}\text { Points } \\
1-3\end{array}$ & $\begin{array}{c}3 \\
(1.00)\end{array}$ & $\begin{array}{c}1 \\
(0.00)\end{array}$ & $\begin{array}{c}2 \\
(0.50)\end{array}$ & & & \\
\hline \multirow{3}{*}{$\exists \begin{array}{c}\stackrel{0}{0} \\
\stackrel{0}{0} \\
\stackrel{0}{0}\end{array}$} & $C_{7}$ & $Q n, D$ & $\mathrm{MJ} / \mathrm{pcs}$ & $\begin{array}{c}9600.00 \\
(0.14) \\
\end{array}$ & $\begin{array}{c}2481.60 \\
(1.00) \\
\end{array}$ & $\begin{array}{c}10723.38 \\
(0.00) \\
\end{array}$ & \multirow{3}{*}{0.41} & \multirow{3}{*}{0.50} & \multirow{3}{*}{0.00} \\
\hline & $C_{8}$ & $Q n, D$ & $\mathrm{~J} / \mathrm{kgK}$ & $\begin{array}{l}840.00 \\
(0.81) \\
\end{array}$ & $\begin{array}{c}2510.00 \\
(0.00) \\
\end{array}$ & $\begin{array}{l}440.00 \\
(1.00) \\
\end{array}$ & & & \\
\hline & $C_{9}$ & $Q n, D$ & $\mathrm{~W} / \mathrm{mK}$ & $\begin{array}{c}0.80 \\
(0.99) \\
\end{array}$ & $\begin{array}{c}0.16 \\
(1.00) \\
\end{array}$ & $\begin{array}{l}58.00 \\
(0.00) \\
\end{array}$ & & & \\
\hline \multirow{3}{*}{$\geq \frac{\mathscr{d}}{\vec{\Xi}}$} & $C_{10}$ & $Q n, D$ & $\mathrm{~kg} / \mathrm{pcs}$ & $\begin{array}{l}480.00 \\
(0.00) \\
\end{array}$ & $\begin{array}{c}264.00 \\
(1.00) \\
\end{array}$ & $\begin{array}{c}324.60 \\
(0.64) \\
\end{array}$ & \multirow{3}{*}{0.50} & \multirow{3}{*}{0.61} & \multirow{3}{*}{0.00} \\
\hline & $C_{11}$ & $Q l, S$ & $\begin{array}{c}\text { Points } \\
1-3\end{array}$ & $\begin{array}{c}3 \\
(1.00) \\
\end{array}$ & $\begin{array}{c}3 \\
(1.00) \\
\end{array}$ & $\begin{array}{c}1 \\
(0.00) \\
\end{array}$ & & & \\
\hline & $C_{12}$ & $Q l, S$ & $\begin{array}{c}\text { Points } \\
1-3\end{array}$ & $\begin{array}{c}3 \\
(1.00)\end{array}$ & $\begin{array}{c}2 \\
(0.50)\end{array}$ & $\begin{array}{c}1 \\
(0.00)\end{array}$ & & & \\
\hline
\end{tabular}




\subsection{Globally evaluation of material variants}

In the second stage, material variants were compared globally based on the adjusted index of summation (AIS) which is calculated on the basis of the following formula [4]:

$$
A I S_{i}=\sum_{j=1}^{m}\left(z_{i j}-v_{j}\right)
$$

where: $i$ - variant's number, $j$ - criterion's number, $m$ - number of all criteria, $z_{i j}$ - measure of $i$-th variant according to $j$-th criterion and $v_{j}$ - weight of $j$-th criterion.

The results obtained after the first part of the analysis for the four groups of criteria were adopted "a priori" for further calculations as partial measures of material variants, which were then encoded according to Neuman-Morgenstern. The degrees of importance (weights) of the groups of criteria, were determined using the expert knowledge in the field of architectural design, construction design and management of building investment projects. In the last step the encoded measures for material variants were calculated including weights of criteria $\left(\left[z_{i j}\right]\right.$ multiplied by $\left.\left[v_{j}\right]\right)$, which were then added to the form of the adjusted index of summation (AIS) to compare and prioritize solutions.

Table 2 presents the results of the analysis obtained in the second stage.

Table 2. The results of the analysis obtained in the second stage.

\begin{tabular}{|c|c|c|c|c|c|c|c|c|}
\hline \multirow{2}{*}{$\begin{array}{c}\text { Groups } \\
\text { of criteria }\end{array}$} & Weight & \multirow{2}{*}{$\begin{array}{c}\text { Type, } \\
\text { char. }\end{array}$} & \multicolumn{4}{|c|}{$\begin{array}{c}\text { Partial and encoded } \\
\text { measures of variants }\end{array}$} & \multicolumn{3}{c|}{$\begin{array}{c}\text { Encoded measures } \\
\text { with criteria weights }\end{array}$} \\
\cline { 4 - 9 } & & $\begin{array}{c}\text { Safety } \\
\text { glass }\end{array}$ & Glulam & $\begin{array}{c}\text { Rolled } \\
\text { Steel }\end{array}$ & $\begin{array}{c}\text { Safety } \\
\text { glass }\end{array}$ & Glulam & $\begin{array}{c}\text { Rolled } \\
\text { Steel }\end{array}$ \\
\hline $\begin{array}{c}\text { I } \\
\text { economic }\end{array}$ & 0.350 & $Q n, S$ & $\begin{array}{c}0.00 \\
(0.00)\end{array}$ & $\begin{array}{c}0.73 \\
(1.00)\end{array}$ & $\begin{array}{c}0.35 \\
(0.48)\end{array}$ & 0.000 & 0.350 & 0.168 \\
\hline $\begin{array}{c}\text { II } \\
\text { aesthetic }\end{array}$ & 0.225 & $Q n, S$ & $\begin{array}{c}0.50 \\
(1.00)\end{array}$ & $\begin{array}{c}0.13 \\
(0.00)\end{array}$ & $\begin{array}{c}0.25 \\
(0.32)\end{array}$ & 0.225 & 0.000 & 0.073 \\
\hline $\begin{array}{c}\text { III } \\
\text { energetic }\end{array}$ & 0.175 & $Q n, S$ & $\begin{array}{c}0.41 \\
(0.82)\end{array}$ & $\begin{array}{c}0.50 \\
(1.00)\end{array}$ & $\begin{array}{c}0.00 \\
(0.00)\end{array}$ & 0.143 & 0.175 & 0.000 \\
\hline $\begin{array}{c}\text { IV } \\
\text { others }\end{array}$ & 0.250 & $Q n, S$ & $\begin{array}{c}0.50 \\
(0.82)\end{array}$ & $\begin{array}{c}0.61 \\
(1.00)\end{array}$ & $\begin{array}{c}0.00 \\
(0.00)\end{array}$ & 0.205 & 0.250 & 0.000 \\
\hline \multicolumn{7}{|c|}{ Adjusted index of summation (AIS ) } \\
\hline
\end{tabular}

\section{Conclusions}

The authors of the study paid particular attention to the following two facts: that today transparent façades clearly mark their presence in building construction and that the requirements placed on them in terms of thermal protection will continue to grow. Legal changes from November 2017 caused a lowering of the heat transfer coefficient values $\left(U_{\max }\right)$, for example, for transparent, non-opening surfaces (including transparent façades, regardless of the type of building) as much as $63.6 \%$ from 1.8 to $1.1 \mathrm{~W} / \mathrm{m}^{2} \mathrm{~K}$, when the temperature inside the heated rooms $\left(t_{i}\right)$ is at least $16^{\circ} \mathrm{C}$. Forecasts suggest that the next legal changes will cause that from the end of 2020 the value $\left(U_{\max }\right)$ for transparent nonopening surfaces will not be more than $0.9 \mathrm{~W} / \mathrm{m}^{2} \mathrm{~K}$. This is related to the European Union's assumptions about the Member States' pursuit of sustainable development, also by the constant reduction of energy consumption by buildings. 
The multi-criteria comparative analysis shows that the best material solution for the 6meter-long reference column is glulam - AIS $=0.775$. The results for other materials were respectively: for safety glass - AIS $=0.573$ and for rolled steel - AIS $=0.241$. The superiority of safety glass over rolled steel was primarily determined by aesthetic and energetic groups of criteria. The comparative analysis also reveals that safety glass is the most attractive material in terms of aesthetics, since the synthetic assessment for safety glass in the first stage of the analysis was the highest in the group of the aesthetic criteria $\left(\mathrm{SA}_{1}=0.50>\mathrm{SA}_{3}=0.25>\mathrm{SA}_{2}=0.13\right)$.

\section{References}

1. A. Jóźwik, Cz. Tech. Arch. 104(4-A), 219-224, (2007)

2. W. Szolginia, Architektura (Wyd. Sigma NOT, Warszawa, 1992)

3. M. Dytczak, Wybrane metody rozwiazywania wielokryterialnych problemów decyzyjnych w budownictwie (Politechnika Opolska, Opole, 2010)

4. J. Szwabowski, J. Deszcz, Metody wielokryterialnej analizy porównawczej (Politechnika Śląska, Gliwice, 2001)

5. T. Trzaskalik, Zesz. Nauk. PŚl, seria : Organizacja i Zarządzanie 74, 239-263, (2014)

6. M. Meller, P. Siwiński, Szkło budowlane (Politechnika Koszalińska, Koszalin, 2002)

7. A. Piekarczuk, Elementy konstrukcyjne ze szkła budowlanego (ITB, Instrukcje, wytyczne, poradniki, Warszawa, 2013)

8. Z. Mielczarek, Nowoczesne konstrukcje w budownictwie ogólnym (Arkady, Warszawa, 2009)

9. E. Neufert, Podręcznik projektowania architektoniczno-budowlanego (Arkady, Warszawa, 2000)

10. A. Bugaj, Rynek Inst. 11, 48-51, (2013)

11. B. Stelmach, Poszukiwania struktur. Prace architektoniczne 1997 - 2011. Tom 2 Zdjęcia z realizacji (Wyd. PAN, oddział w Lublinie, 2012)

12. http://www.ots-ip.pl/wp-content/uploads/2014/03/Untitled-11.jpg (access date: 15. Jan. 2018)

13. http://www.polskiekrajobrazy.pl/images/stories/big/27418.. Zelazowa Wola i okolice .JPG (access date: 15. Jan. 2018)

14. M. Gicala, A. Sobotka, Prz. Nauk. Inż. i Środ. 26(2), 159-170, (2017)

15. A. Leśniak, K. Zima, International Multidisciplinary Scientific GeoConference Surveying Geology and Mining Ecology Management (SGEM, Albena, Bulgaria) 3(5), 157-164, (2015)

16. W. Drozd, Prz. Bud. 84(4), 32-37, (2013)

17. A. Leśniak, J. Balicki, Entrepr. Bus. and Econ. Rev. 4(2), (2016)

18. A. Radziejowska, K. Zima, E3S Web of Conferences 10(00078), (EDP Sciences, 2016)

19. M. Golański, Bud. i Inż. Środ. 3, 39-53, (2012)

20. J. Górzyński, Podstawy analizy środowiskowej wyrobów i obiektów (WNT, Warszawa, 2007)

21. A. Leśniak, A. Radziejowska, Proc. Eng. 208, 76-81, (2017)

22. E. Plebankiewicz, K. Zima, D. Wieczorek, Arch. of Civ. Eng. 62(2), 149-166, (2016) 